\title{
PEDAGOGIC DIAGNOSTIC METHODS OF JUVENILE CONVICTS SOCIAL HEALTH: EXPERIMENTAL STUDY
}

\author{
Irina Ganishina \\ Academy of Law and Management of the Federal Penitentiary Service of Russia, \\ the Russian Federation \\ Ella Podnebesnaya \\ Academy of Law and Management of the Federal Penitentiary Service of Russia, \\ the Russian Federation
}

Albina Mamedova

Ryazan State University named for S. Yesenin, the Russian Federation

Nina Tyugaeva

Academy of Law and Management of the Federal Penitentiary Service of Russia, the Russian Federation

Nikolay Tkachenko

Academy of Law and Management of the Federal Penitentiary Service of Russia, the Russian Federation

\section{Marina Ovsyannikova}

Academy of Law and Management of the Federal Penitentiary Service of Russia, the Russian Federation

\begin{abstract}
Convicts social health is regarded by the authors of the article as the state of social welfare including the ability to support the socially healthy relationships in the society. To diagnose this state of ability among the juvenile convicts serving sentences in the correctional colonies is of special importance. According to the experimental study there is not enough work done to develop social health among juvenile convicts in the places where the imprisoned are stayed. The hypothesis of the investigation is the assumption that to form the social health among convicted male minors in the juvenile correctional facility will be more successful if they participate in the project "Book is the source of new life and the way to rehabilitation." To diagnose the state of social health of juvenile convicts the following methods and techniques have been used, they are watching, talking, summative assessment, formative assessment, testing, The Test of Viability by D.A. Leontyev, The Questionnaire: Health, Activity, Mood (by V.A. Doskin, N.A. Lavrentyeva, V.B. Sharay, M.P. Miroshnikov); Success Stimuli and Failure Fear methods by A.A. Rean. The summative assessment procedure was held in March 2019, the formative assessment experiment had been conducted for 3 months (from April till June 2019). The summative assessment has shown that juvenile convicts have weak viability, reduced level of well-being, and activity, and mood as well; there is a low level of success stimuli and high
\end{abstract}


level of failure fear. The results of formative assessment have shown that the participation in the Project helps to form viability, activity, cheering up, decreasing of failure fear, increasing of success motivation; and it assists conforming social health of juvenile convicts as a whole.

Keywords: formative assessment, juvenile convicts, pedagogic diagnostic methods, summative assessment, social health.

\section{Introduction}

Nowadays there is a steady trend to deterioration of the health of the population especially of juveniles. Unfavourable micro-social conditions of living and upbringing, negative dynamics of moral values of the society are considered to be the main reasons affecting the health conditions of the juveniles.

The weakening of the educational function of the family, child abuse, stress expansion and conflict situation increase, the media propaganda of violence, cruelty, obscenity, greed, the falsity, betrayal and other factors lead to the fact that the juveniles having made crimes and serving a sentence in prisons constitute crime prone part of the population. That's why at present a current demand arises among the members of the modern society to maintain social health of juvenile convicts, serving a sentence in educational colonies.

\section{Theoretical basis of investigating of juvenile convicts' social health}

One of the approaches to studying the phenomenon of healthy individual, underlying the social health notion is the understanding of it as the form of social interaction of the individual and regarding it as a social structure unit of a society.

The works by A. Adler (Adler, 1997), A. Maslow (Maslov, 1999) are devoted to the study of health of the individuals. The problems of social health were studied by B.C. Bratus (Bratus, 2004), O.S. Vasilyeva (Vasilieva, 2005), G.S. Nikiforova (Nikiforov, 2003), I.V. Dubrovina (Dubrovina, 1991), O.V. Huhlaeva (Huhlaeva, 2005), L.A. Baikova (Baykova, 2006), E.I. Podnebesnaya (Podnebesnaja, 2010) and others.

Social health is regarded by the scientists as a complicated social phenomenon, originated in the process of interaction between the individual and social environment, reflecting the level of this interaction. The analysis of the foreign literature allows assuming that social health implies the ability of an individual to form satisfied interpersonal relations with others. Every healthy relation should include strong communicative skills, sympathy for other people and a sense of responsibility (Rogers, 1994; Huhlaeva, 2005).

In the light of our research we are of the view of M. Yen, who regards social health as 'an aspect of human wellbeing, which deals with his/her capacity to get along with other people, how other people respond to him/her activity and how 
an individual interact with social institutions and follow with moral norms of society' (Kasser \& Ryan, 1996). This definition includes the elements of the psychological structure of an individual and his/her social skills, reflects social norms and is close to such notions as wellbeing, adaptation, social functioning, harmony (Sheldon \& Kasser, 1995). In the light of our research social health may be regarded as the reflection of the attitude of the society to the individual and is implemented through his/her participation in various social communities.

According to the ideas of humanistic psychology and axiological approach (Maslow, 1999), (Rogers, 1994); the ideas of metasystematic approach to social health study (Petrovsky, 1982), (Baykova, 2006; Kolpina, 2017), a healthy type of relations of an individual and environment is that kind of interaction when a person is included in the social communities harmonically, and has an opportunity meet his/her demands, not violating and not destroying dramatically the society.

Globalization of the modern society caused the new negative tendencies of transformation and degradation of a developing personality of an individual and juvenile as well and it has influenced their social life negatively (Hanishina \& Usatikov, 2006). Social health is an integrative quality of an individual characterized by harmonious relationships with coevals, and other social groups, the relation with the social medium, with the society. Social health stimulates effective development of an individual and positive influence on the society (Petrovsky, 1982; Ter-Gevorkova, 2019).

According to some investigations social health of the juveniles may be regarded as pathological (Podnebesnaja, 2010), because they have below level of motivation of success, of social activity and vitality.

So we regard social health of juvenile convicts as the state of social wellbeing, including the ability to maintain social-healthy relations in the society.

\section{The Analysis of Empiric Research of the Social Health Indicators of Juvenile Convicts and Their Experimental Formation}

According to the Conception of Criminal-Punishment System Development of the Russian Federation to 2020, signed by the Russian Federation Government Resolution from Oct.14, 2020 No 1772-p, one of the important condition of correction and successful adaptation to the society after release is to ensure social, psychological and educational work with the convicts.

Social adaptation of the convicts is very important, to rehabilitate them to be adjusted to a new way of living after release. To rehabilitate the juvenile convicts is not less important, to develop their personality and form social health. Thus in the system of prison a specific closed socio-cultural community is formed, where socialization of the juvenile convicts is made. 
Experimental work was carried out in 2019 in the educational colony for convicted male minors in several stages: I stage is preparatory; II stage is ascertaining experiment; III stage is forming experiment; IV stage is analytical and generalizing.

At the preparatory stage the following tasks were solved:

1) selection of methods and techniques of diagnostics of social health level of juvenile convicts;

2) development of pedagogical conditions of the organization of educational process within the project "Book is the source of new life and a way to correction and rehabilitation" to strengthen juvenile convicts' social health.

In the conditions of an educational colony, a book for a juvenile convict is the only guide on the path of correction, which involves not only changing the worldview to the socially demanded, but also obtaining knowledge and skills of effective interaction with other people in a free society. The project "Book is the source of new life and a way to correction and rehabilitation" is aimed at forming a socio-cultural environment changing the worldview of those who serve sentences staying in prison according to the penitentiary system of the Federal System of Inspection and Punishment of Russia.

According to the rules of pedagogical experiment we selected control group (35 people) and experimental group (35 people). During the pedagogical experiment, the control group was not influenced, the experimental group had been influenced for three months (the juvenile convicts of this group took part in the project "Book is the source of new life and a way to correction and rehabilitation").

We selected the following methods of pedagogical diagnostics: The Test of Viability by D.A. Leontyev (Golovey \& Rybalko, 2002); Success Stimuli and Failure Fear Test by A.A. Rean (Golovey \& Rybalko, 2002); The Questionnaire: Health, Activity, Mood by V.A. Doskin, N.A. Lavrentyeva, V.B. Sharay, M.P. Miroshniko (Golovey \& Rybalko, 2002).

In accordance with the developed plan of the experimental work, the second stage (March 2019) provided for carrying out the ascertaining experiment. Its purpose was with the help of selected methods and techniques to identify the severity of vitality, the level of motivation for success and fear of failure, the activity, as the components of juvenile convicts social health indicators.

The ascertaining experiment, in which 70 male juvenile convicts participated, showed a low level in the respondents on the scales of "Well-Being", "Activity" and "Mood", which indicates that they have a state of discomfort, passivity, inertia and a predominance of feelings of longing and boredom. 
SOCIETY. INTEGRATION. EDUCATION

Proceedings of the International Scientific Conference. Volume VI, May $22^{\text {th }}-23^{\text {th }}, 2020.228-235$

$70 \%$ of respondents expressed fear of failure, which indicates anxiety and uncertainty in their abilities. Juvenile convicts do not assume the possibility of success (Fig.1).

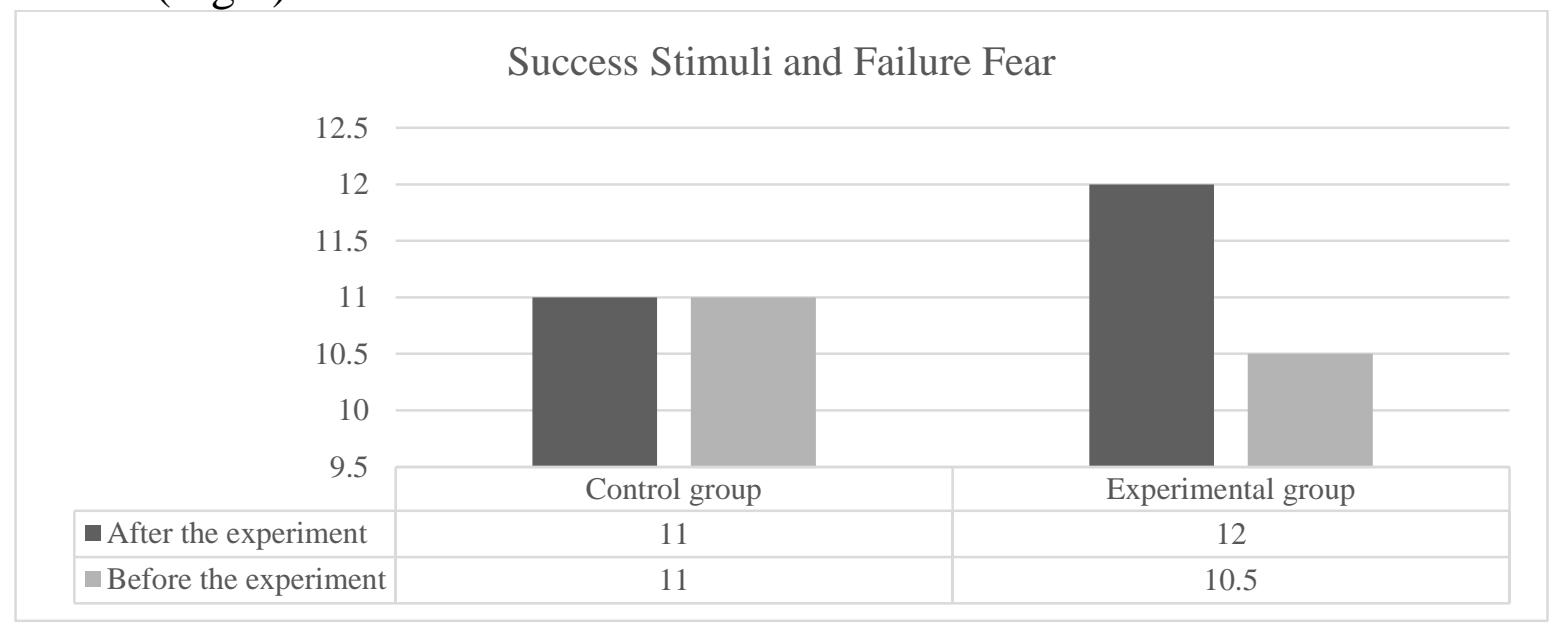

Figure 1 Motivation for success and fear of failure among juvenile convicts

It was revealed that the majority of juvenile convicts (60\%) have a low level of resilience (Fig.2), which constitutes certain difficulties for minors in the process of serving a criminal sentence in prison.

Resilience is a system of believes that promotes an individual to manage extreme situations, perceive negative events as experiences and successfully cope with them. Resilience is an important psychological quality necessary for survival in difficult living conditions, including in the conditions of an educational colony.

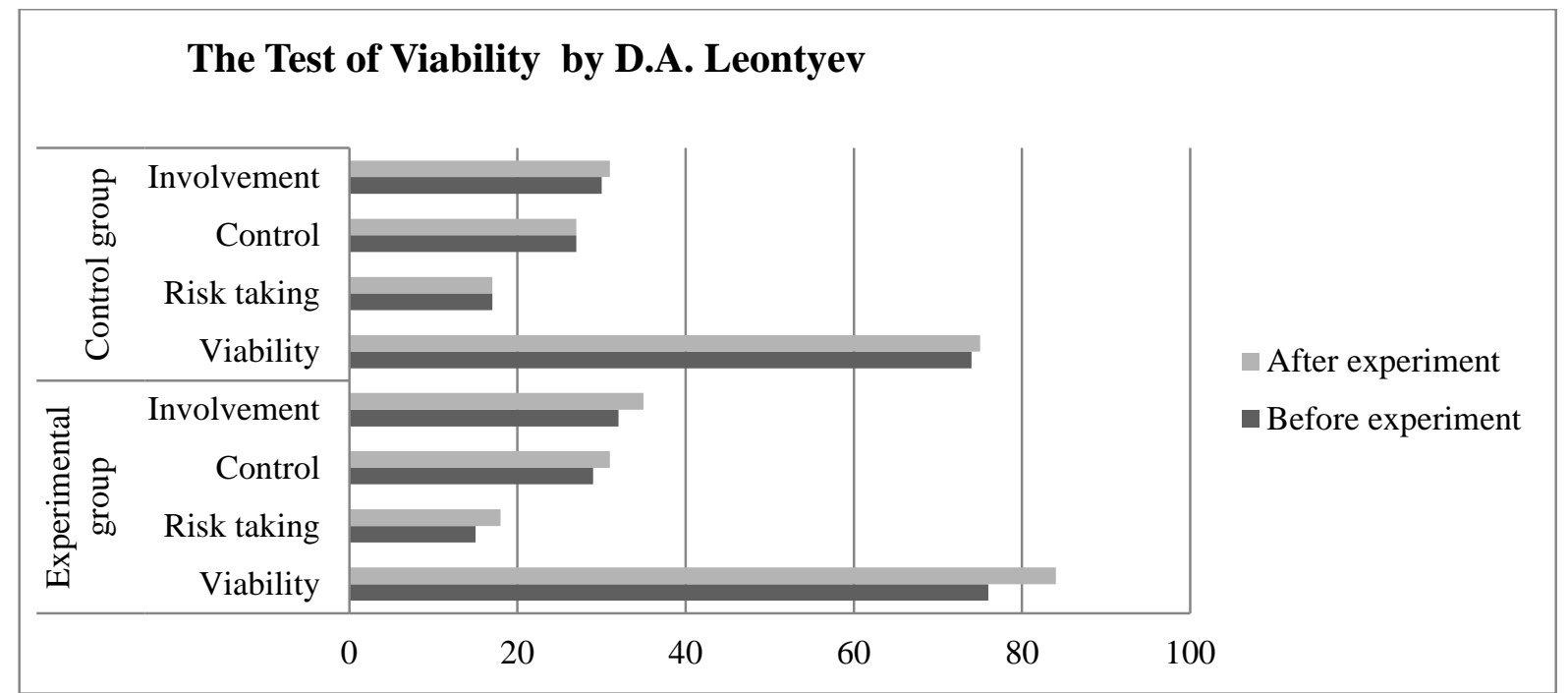

Figure 2 The rate of viability for juvenile offenders 
At the third stage of the experimental work (April-June 2019) we conducted a formative pedagogical experiment. The educational purpose of the formative experiment was to develop and strengthen the social health of juvenile convicts in the framework of the project "the Book is a source for a new life and a path to correction". With the help of a formative experiment, we implemented the following areas of work with the book: book exhibitions "The whole world is a library", "Reading Land"; literary and musical evenings "Yesenin Motherland", "Visiting Pushkin"; loud readings followed by analysis of the reading materials; poetic hours; literary brain-rings "Among the Favourite Books", "Writers of our Childhood"; round table " To Read or not To Read?", "Reading Youth".

Special attention was paid to dialogue forms and creative works (writing essays). Juvenile convicts expressed their opinion on various issues and defended it, thought, gave reasons, listened, learned to communicate, used interpersonal communication. Thus, a single collective opinion, a collective mood on the studied event, phenomenon was formed. Within the framework of an essay writing, reflection was very often used.

The analysis of the results of the diagnosis by the method of Health, Activity, Mood " SAN "showed a fairly high level of respondents on the scales of "Health", "Activity" and "Mood", which indicates their impetuosity, initiative, enthusiasm. The juvenile convicts show an emotional response to various influences and it is actively manifested.

The formative experiment showed that the majority of juvenile convicts (40 \%) increased the level of resilience (Fig. 2). They showed self-confidence, the presence of goals for the future, involvement in the life activity, openness, willingness to act in the absence of guarantees of success, based on their own experience, the idea of themselves as a strong person, able to control their lives. The convicts became convinced of the possibility to influence the results of their activities with success.

The majority of respondents of respondents, the fear of failure is expressed weakly and the desire to achieve success is manifested, which indicates a decrease in anxiety, uncertainty in their abilities (Fig. 1).

Thus, in the course of an empirical study and a formative experiment, we were able to diagnose and improve the social health of juvenile convicts serving sentences in prison.

\section{Conclusions}

Within the framework of the project "Book is a source for a new life and a way to correction", being in isolation, experiencing psychological discomfort, juvenile convicts under the leadership of the heads of units, educators and psychologists find positive emotions, the possibility of self-development, 
knowledge, skills formation, assimilation of norms, values, attitudes of society, they learn to build social ties. The conducted pedagogical experiment plays in an important role in the formation of such qualities of juvenile convicts in the educational colony as: adaptation to the social environment (internal and external); social orientation, manifested in the willingness to solve socially significant problems; social activity; awareness of the social significance of their actions; readiness for self-development; creativity. The experiment revealed the severity of vitality, the level of motivation for success and fear of failure, activity as components of social health of juvenile convicts.

In the course of the pedagogical experiment within the socio - cultural environment of the educational colony, during the implementation of the project "Book is the source of new life and the way to correction", we carried out pedagogical activities aimed at the formation and development of social health of male juvenile convicts. The conducted experiment allowed to state that for juvenile convicts work with a book is a link between what is read and what is read for; between how to adapt to the educational colony, and how to change their consciousness and behaviour in the new society after release.

\section{References}

Adler, A. (1997). Understand human nature. SPb.: Academic project.

Baykova, L. (2006). Social health: methodological and theoretical bases of research. Psychology of health: methodology, theory and practice: materials of interregional scientific and practical conference. Ryazan: RSPU.

Bratus, B. (2004). Studying of semantic sphere of the personality. Vestnik of Moscow University. Series 14: Psychology, 2, 46-56.

Dubrovina, I. (1991). School psychological service: Questions of Theory and Practice. Moscow: Pedagogy.

Golovey, L., \& Rybalko, E. (2002). Practical Work on the Age Psychology. SPb.: Speech.

Hanishina, I., \& Usatikov, A. (2006). Moscow. Ser. Library of the teacher-practice. Russian Academy of Sciences. Education, Moscow psychological and social Institute.

Huhlaeva, O. (2005). Psychology of a teenager: proc. benefit. Moscow: "Academy".

Kasser, T., \& Ryan, R.M. (1996). Further Examining the American Dream. The Different Correlations of Intrinsic and Extrinsic Goals. Personal and Social Psychology Bulletin, 22, 80-87.

Kolpina, L. (2017). Social'noe zdorov'e: opredelenie i mexanizmy vliyaniya na obshhee zdorov'e Sinergiya.

Maslow, A. (1999). Motivation and personality. St. Petersburg: Eurasia.

Petrovsky, A. (1982). Personality. Activity. Collective. Moscow: Politizdat.

Podnebesnaya, E. (2010). Pedagogical aspects of the formation of social health of adolescents: thesis ... cand. pedagogical. sciences'. Ryazan.

Psychology of health / edited by G.S. Nikiforov. (2003). SPb.: Peter.

Rogers, K. (1994). View on psychotherapy. The formation of man. Moscow.

Sheldon, K. M., \& Kasser, T. (1995). Coherence and congruence: Two aspects of personality integration. Journal of personality and social psychology, 68(3), 531. 
Ganishina et al., 2020. Pedagogic Diagnostic Methods of Juvenile Convicts Social Health: Experimental Study

Ter-Gevorkova, N. (2019). Social'noe zdorov'e sovremennoj molodezhi rossijskogo obshhestva. Molodoj uchenyj, 237-241.

The Order of the Government of the Russian Federation of October 14, 2010 N 1772-R about the adoption of the Concept of Development of criminal Executive System of the Russian Federation till 2020 (with changes and additions).

Vasilieva, O. (2005). Psychology of human health: measurement standards, presentation, installation. Moscow: "Academy". 